\title{
CT VS Transcranial Ultrasound-A Diagnostic Tool in Hypoxic Ischaemic Encephalopathy-A 2 Year Study
}

\author{
Authors \\ Shamim Nisa ${ }^{1}$, P.K. Mishra ${ }^{2}$, V. Goguldeep ${ }^{3}$, B.B. Panda ${ }^{4}$, B. Das ${ }^{5}$, S. Bhagat ${ }^{6}$ \\ ${ }^{1,4,5}$ Associate Professors, VIMSAR, Burla \\ ${ }^{2,3}$ PG Residents, VIMSAR, Burla \\ ${ }^{6}$ Professor and HOD, VIMSAR, Burla \\ Corresponding Author \\ V. Goguldeep \\ PG Resident, VIMSAR, Burla, Sambalpur, Odisha-768017,India \\ Email: goguldr@gmail.com
}

\begin{abstract}
Hypoxic ischaemic encephalopathy (HIE) is a neurological manifestation in neonates due to asphyxia to the fetus- intranatal, natal and post natal period.

The study was conducted to evaluate imaging findings in preterm and term infants diagnosed clinically as HIE. 60 cases with birth asphyxia during DEC 2013 to NOV 2015 were subjected to transcranial USG \& CT scan evaluation. Results were compared and found USG superior to CT scan in premature infants
\end{abstract}

Keywords: Hypoxic ischemic encephalopathy, CT, USG, Birth asphyxia, preterm and term.

\section{INTRODUCTION}

HIE is a disturbed neurological function in neonates manifested by difficulty with initiating and maintaining respiration, depression of tone and reflexes ,subnormal level of consciousness \& often seizures.. HIE is the morbid consequence of perinatal asphyxia which leads to permanent damage to CNS and finally result in either neonatal death or make them neurologically handicapped. It is a major long term neurological sequel in childhood and has been a major concern to both the neonatologist and the neurologist. Till 1980 CT was accepted the method for demonstrating the brain in neonates and infants. But it is expensive, time consuming and has radiation hazards.In contrast transcranial USG is straight forward, easy, cost effective and has no ionizing radiation.

\section{AIM AND OBJECTIVE}

- To detect the presence of intracranial changes in preterm/full term infants suffering from birth asphyxia by transcranial USG and CT scan

- To correlate and compare both the modalities

- To follow the sequelae and the changes over an year 


\section{JMSCR Vol||05||Issue||01||Page 15153-15156||January}

\section{MATERIALS AND METHODS}

A prospective study of 60 cases (36 preterm and 24 term infants) with clinical features of neonatal intracranial hypoxic ischemia was conducted during the period between Dec 2013 to Nov 2015 in the department of Radio diagnosis, VIMSAR, Burla.. The present study was undertaken to assess the neurosonographic abnormalities in preterm and full term infants with moderate to severe birth asphyxia with the help of transfontanelle sector real time USG and CT scan

A provisional clinical staging of HIE was based on modified Sarnat \& Sarnat method. Transcranial USG was done in PHILIPS HD 7 machine with grey scale imaging. .

\section{RESULTS}

\section{Table 1.}

9 Cases of periventricular injury was diagnosed on USG, whereas CT diagnosed only 4 cases, 3 cases of brainstem injury were diagnosed on CT whereas USG diagnosed none, 7 cases of diffuse cerebral injury were diagnosed on USG, whereas CT diagnosed 4 cases .

\section{TABLE - 1 : IMAGING FEATURES (CT \& USG)}

\section{IN PRETERM}

\begin{tabular}{|c|c|c|c|c|c|c|c|}
\hline \multirow[b]{2}{*}{ SLNO. } & \multirow[t]{2}{*}{ IMAGING FEATURES } & \multicolumn{2}{|c|}{ CT } & \multicolumn{2}{|c|}{ USG } & \multirow[b]{2}{*}{$\begin{array}{c}p \\
\text { Value } \\
\end{array}$} & \multirow[b]{2}{*}{ Significance } \\
\hline & & $\begin{array}{l}\text { NOOF } \\
\text { CASES }\end{array}$ & $\%$ & $\begin{array}{l}\text { NOOF } \\
\text { CASES } \\
\end{array}$ & $\%$ & & \\
\hline 1 & $\begin{array}{c}\text { GERMINAL MATRIX HEMORRHAGE\& } \\
\text { IVH (GMH \& IVH) }\end{array}$ & 8 & $22.2 \%$ & 8 & $22.2 \%$ & 1.000 & Not Significant \\
\hline 2 & $\begin{array}{c}\text { PERIVENTRICULAR LEUKOMALACIA } \\
\text { (PVEIPWW) }\end{array}$ & 4 & $11.1 \%$ & $g$ & $25.0 \%$ & 0.119 & Not Significant \\
\hline 3 & DIFFUSE INUURY (DI) & 4 & $11.1 \%$ & 7 & $19.4 \%$ & 0.322 & Not Significant \\
\hline 4 & $\begin{array}{c}\text { BASAL GANGLLA\& THALAMIC INUURY } \\
\text { (CG|BGI) }\end{array}$ & 5 & $13.9 \%$ & 5 & $13.9 \%$ & 1.000 & Not Significant \\
\hline 5 & BRANSTEM HEMORRHAGE (BH) & 3 & $8.3 \%$ & 3 & $8.3 \%$ & 1.000 & Not Significant \\
\hline 6 & BRANSTEM INFARCTS (BSI) & 3 & $8.3 \%$ & 0 & $0.0 \%$ & 0.040 & Significant \\
\hline 1 & PARENCHYMAL HEMORRHAGE (PH) & 2 & $5.6 \%$ & 1 & $2.8 \%$ & 0.554 & Not Significant \\
\hline 8 & CEREBELLARHEMORRHAGE (CDH) & 1 & $2.8 \%$ & 1 & $28 \%$ & 1.000 & Not Significant \\
\hline 9 & MFH & 2 & $5.6 \%$ & 1 & $2.8 \%$ & 0.554 & Not Significant \\
\hline 10 & NORMAL (N) & 13 & $36.1 \%$ & 8 & $22.2 \%$ & 0.190 & Not Significant \\
\hline
\end{tabular}

\section{TABLE 2: IMAGING IN TERMS}

\begin{tabular}{|c|c|c|c|c|c|c|c|}
\hline & $\begin{array}{l}\text { IMAGING } \\
\text { FEATURES }\end{array}$ & C & & US & & & \\
\hline $\begin{array}{l}\text { SL } \\
\text { NO. }\end{array}$ & & $\begin{array}{l}\text { NO OF } \\
\text { CASES }\end{array}$ & $\%$ & $\begin{array}{l}\text { NO OF } \\
\text { CASES }\end{array}$ & $\%$ & $\begin{array}{c}P \\
\text { Value }\end{array}$ & Significance \\
\hline 1 & $\begin{array}{l}\text { MULTIFOCAL } \\
\text { HYPODENSITIES } \\
\text { (MFH) }\end{array}$ & 6 & $25.0 \%$ & 2 & $8.3 \%$ & 0.112 & $\begin{array}{c}\text { Not } \\
\text { Significant }\end{array}$ \\
\hline 2 & $\begin{array}{c}\text { CORTICAL \& } \\
\text { SUBCORTICAL } \\
\text { INJURY (CI\&SCI) }\end{array}$ & 5 & $20.8 \%$ & 2 & $8.3 \%$ & 0.213 & $\begin{array}{c}\text { Not } \\
\text { Significant }\end{array}$ \\
\hline 3 & $\begin{array}{l}\text { PARASAGITTAL } \\
\text { INJURY } \\
\text { (PSI) }\end{array}$ & 2 & $8.3 \%$ & 0 & $0.0 \%$ & 0.140 & $\begin{array}{c}\text { Not } \\
\text { Significant }\end{array}$ \\
\hline 4 & $\begin{array}{c}\text { BASAL GANGLIA } \\
\text { INJURY } \\
\text { (CGIBGI) } \\
\end{array}$ & 3 & $12.5 \%$ & 3 & $12.5 \%$ & 1.000 & $\begin{array}{c}\text { Not } \\
\text { Significant }\end{array}$ \\
\hline 5 & $\begin{array}{l}\text { BRAINSTEM } \\
\text { INJURY (BSI) }\end{array}$ & 1 & $4.2 \%$ & 0 & $0.0 \%$ & 0.307 & $\begin{array}{c}\text { Not } \\
\text { Significant }\end{array}$ \\
\hline 6 & $\begin{array}{c}\text { DIFFUSE } \\
\text { CEREBRAL EDEMA } \\
\text { (DI) }\end{array}$ & 5 & $20.8 \%$ & 12 & $50.0 \%$ & 0.027 & Significant \\
\hline 7 & $\begin{array}{l}\text { INTRAVENTRICULA } \\
\text { RHEMORRHAGE } \\
\text { (IVH) }\end{array}$ & 4 & $16.7 \%$ & 4 & $16.7 \%$ & 1.000 & $\begin{array}{c}\text { Not } \\
\text { Significant }\end{array}$ \\
\hline 8 & $\begin{array}{c}\text { BRAINSTEM } \\
\text { HEMORRHAGE } \\
\text { (BH) }\end{array}$ & 1 & $4.2 \%$ & 1 & $4.2 \%$ & 1.000 & $\begin{array}{c}\text { Not } \\
\text { Significant }\end{array}$ \\
\hline 9 & $\begin{array}{c}\text { PARENCHYMAL } \\
\text { HEMORRHAGE } \\
\text { (IPH) }\end{array}$ & 2 & $8.3 \%$ & 1 & $4.2 \%$ & 0.550 & $\begin{array}{c}\text { Not } \\
\text { Significant }\end{array}$ \\
\hline 10 & $\begin{array}{l}\text { EXTRA-AXIAL } \\
\text { HEMORRHAGE } \\
\text { (EAH) }\end{array}$ & 2 & $8.3 \%$ & 0 & $0.0 \%$ & 0.140 & $\begin{array}{c}\text { Not } \\
\text { Significant }\end{array}$ \\
\hline 11 & $\begin{array}{ll}\text { NORMAL } & \text { (N) }\end{array}$ & 3 & $12.5 \%$ & 10 & $41.7 \%$ & 0.213 & $\begin{array}{c}\text { Not } \\
\text { Significant }\end{array}$ \\
\hline
\end{tabular}

Table 2.Diffuse cerebral echogenicities with effaced cortical sulci suggesting edema was the most common findings on USG seen in 12 neonates where CT suggested multifocal hypodensities and diffuse cerebral injury occurring almost in equal proportions in terms.

TABLE 3 PRETERMS VS TERMS

\begin{tabular}{|c|c|c|}
\hline & \multicolumn{2}{|c|}{ GESTATIONAL AGE } \\
\hline & $<37$ WEEKS (preterms) & $>37$ WEEKS(terms) \\
\hline CT ABNORMALITIES & $23(63.8 \%)$ & $21(87.5 \%)$ \\
\hline USG ABNORMALITIES & $28(77.7 \%)$ & $16(66.7 \%)$ \\
\hline
\end{tabular}

CT detected abnormalities in 23 preterms $(63.8 \%)$ and 21 terms $(87.5 \%)$, whereas USG detected abnormalities in 28 preterms $(77.7 \%)$ and 16 terms $(66.7 \%)$. 
TABLE NO.4 CLINICAL FEATURES VS IMAGING AT FOLLOW -UP IN PRETERMS

(A) CT

\begin{tabular}{|c|c|c|c|c|c|}
\hline \multirow[t]{2}{*}{ CT FINDINGS } & \multicolumn{4}{|c|}{ CLINICAL PRESENTATIONS } & \multirow[b]{2}{*}{ TOTAL } \\
\hline & $\begin{array}{l}\text { FOCAL } \\
\text { SEIZURE }\end{array}$ & $\begin{array}{c}\text { RECURRENT } \\
\text { SEIZURE }\end{array}$ & $\begin{array}{c}\text { SPASTIC } \\
\text { DIPLEGIA }\end{array}$ & $\begin{array}{c}\text { CEREBRAL } \\
\text { PALSY }\end{array}$ & \\
\hline NORMAL & 1 & 0 & 0 & 0 & 1 \\
\hline $\begin{array}{l}\text { CEREBRAL } \\
\text { ATROPHY }\end{array}$ & 0 & $2(50 \%)$ & 0 & $2(50 \%)$ & 4 \\
\hline $\begin{array}{l}\text { VENTRICULAR } \\
\text { DILATATION }\end{array}$ & 0 & $1(25 \%)$ & 0 & & 1 \\
\hline $\begin{array}{c}\text { MULTICYSTIC } \\
\text { ENCEPHALO- } \\
\text { MALACIA }\end{array}$ & 0 & 0 & $2(75 \%)$ & $\begin{array}{c}2(1 \\
\text { neonate } \\
\text { also } \\
\text { presented } \\
\text { with } \\
\text { diplegia) }\end{array}$ & 4 \\
\hline PORENCEPHALY & 0 & $\begin{array}{c}1 \text { (also } \\
\text { presented } \\
\text { with diplegia) }\end{array}$ & 0 & 0 & 1 \\
\hline $\begin{array}{l}\text { PVE WITH } \\
\text { CYSTS }\end{array}$ & 0 & 0 & $1(25 \%)$ & 0 & 1 \\
\hline TOTAL & 1 & 4 & 3 & 4 & 12 \\
\hline
\end{tabular}

\section{B.USG:}

\begin{tabular}{|c|c|c|c|c|c|}
\hline \multirow[t]{2}{*}{ USG FINOINGS } & \multicolumn{4}{|c|}{ CLINICAL PRESENTATIONS } & \multirow[b]{2}{*}{ TOTAL } \\
\hline & $\begin{array}{l}\text { FOCAL } \\
\text { SEIZURE }\end{array}$ & $\begin{array}{l}\text { RECURRENT } \\
\text { SEIZURE }\end{array}$ & $\begin{array}{l}\text { SPASTIC } \\
\text { DIPLEGIA }\end{array}$ & $\begin{array}{c}\text { CEREBRAL } \\
\text { PALSYY }\end{array}$ & \\
\hline NORMAL & 1 & 0 & 0 & $2(50 \%)$ & 3 \\
\hline $\begin{array}{l}\text { CEREBRAL } \\
\text { AIROPHY }\end{array}$ & 0 & $2 \mid 50 \%$ & 0 & 0 & 2 \\
\hline $\begin{array}{l}\text { VENTRICULAR } \\
\text { DILATATION }\end{array}$ & 0 & $1(25 \%)$ & 0 & 0 & 1 \\
\hline $\begin{array}{l}\text { MULIICYSTHC } \\
\text { ENCEPHALO- } \\
\text { MALACIA }\end{array}$ & 0 & 0 & $2(75 \%)$ & $2(50 \%)$ & 4 \\
\hline PORENCEPHALY & 0 & $\begin{array}{c}\text { 1)also } \\
\text { prest'ted } \\
\text { with dipiegal }\end{array}$ & 0 & 0 & 1 \\
\hline PVE WHTH CYSTS & 0 & 0 & $1(25 \%)$ & 0 & 1 \\
\hline TOTAL & 1 & 4 & 3 & 4 & 12 \\
\hline
\end{tabular}

Table 4. Of the infants presenting with recurrent seizure and spastic diplegia had cerebral atrophy and multi-cystic encephalopathy respectively in both the imaging modalities. These findings were noted in both the pre-term and term babies.

\section{DISCUSSION}

Table 1 (Imaging Vs Age at presentation in preterms and terms)

Most cases of PVWI was diagnosed on USG, whereas CT diagnosed less number of cases, which tally with other studies as Siegel M.N., Shoekel Ford GD, Perlman JM \& Fulling KH1 noted that USG was very effective in evaluation of PVWI particularly cystic on necrotic component.

BSI was diagnosed on CT, which could not be assessed by USG. This suggest better efficacy of VT over USG in diagnosing BSI being significant with $\mathrm{P}$ value $<0.05$, BSI being peripheral on USG views, in lesion are often missed.

GMH with IVH was diagnosed with equal accuracy both on CT and VSG. This study by Khanna G, Kapoor RK, Misra PK, Sriastava KL, Pant MC, Srivastava PK2 says that in preterm babies abnormalities included GMH \& IVH in same prepertion of care.

USG detected more DCI as increased echogenicities with effaced sulci and fissures as suggested in a study by Epelman et al., 20103 who described imaging changes including echogenicities of the deep grey matter (basal ganglia and thalami), brainstem and the PVWI.

\section{Table. 2}

In term babies - DCI with effaced cortical sulci suggesting edema was the most common finding on UGS seen in more cases than CT, which showed $\mathrm{MFH}$ and DCI seen in almost equal proportion in terms. This is in agreement with account given by Volpes JJ4 that says CT scan is of is of particular value in identification of focal and multifocal Ischemic injuries.

DCI was better appreciated on USG than CT with a significant difference with Pvalue $<0.05$. This providing is in agreement with other studies carried out by Anand NK, Gupta NK, Lamba IM5.

Cortical and SCI was detected in CT more than USG. Parasagittal in farcts were noted on CT but missed in USG. A care of BSI was detected in CT missed in USG. These lesions being peripherally located are difficult in appreciate and are often missed on Sonography. This is in accordance to a study by J. Volpe.

CT detected IPH more than USG term infant with flaccidity showed ICH on both CT and USG, it showed IPH on CT but not on USG. Similarly cases 
with hypotonia presented predominantly with upper limb weakness were shown to have parasagittal injury in CT which was missed on USG. Similarly finding was noted byVolpes JJ (Neurology of Newborn ed4, Philadelphia 2001, W.B. Saunders)6

\section{Table. 3.}

CT \& USG abnormalities were depicted in preterm and term babies, which showed better efficacy of USG over CT on preterm and CT shows better than USG in terms. This study matches with study by Zhonghua Yi et al.7

\section{Table 4.}

Imaging in follow up cases preterm and terms babies in preterm infant with recurrent seizures had cerebral palsy, but multicystic encephalopathy were presented with spastic diplegia. Imaging modalities showed ventricular dilatation, widening of CSF spaces and leukomalacia in both USG and CT again porencephalic cyst was seen in infant presenting with seizures and spastic diplegia. Similar findings were shown by de Vries et al. 19878, who described children with very extensive cystic leukomalacia invariably developed cerebral palsy mild to moderate types of ischaemic injury suggesting partial Hypoxia cases were commonly diagnosed by USG. Hence the classification of imaging findings into mild moderate and severe degree have been done on the basis of accounts given by Huang \& Castillo in 2008 in Peadiatric neurology byValpe9. So there is a strong co-relation of USG grading by $\mathrm{P}$ value $<0.001 \mathrm{AK}$ Anand et al, 1994 reported similar findings.

\section{CONCLUSION}

Transcranial USG is better tool for early diagnosis of HIE in the preterm infants in the first few days of life. After a few days both USG and CT scan fare equally for term babies CT fares better than USG at any stage. But in long term, CT fares marginally better than USG.

\section{ABBREVIATIONS}

IVH- intra ventricular haemorrhage
IPH- intraparenchymal haemorrhage

MFH- multifocal hypodensity

PVWI- periventricular white matter injury

SAH- subarachnoid haemorrhage

USG- Ultrasonography

CUS-Cranial ultrasonography

BSI-Brain stem injury

GMH-Germinal matrix haemorrhage

DCI-Diffuse cerebral injury

Funding: None

Conflict of interest: No

\section{BIBLIOGRAPHY}

1. Siegel M.N., Shoekel Ford GD, Perlman JM \& Fulling KH: Hypoxic ischaemic injury in term infants - Diagnostic \& prognostic evaluation by USG 152:395-399,1989)

2. Khanna G, Kapoor RK, Misra PK, Srivastava KL, Pant MG,Srivastava , PK.: Computed tomography of brain in symptomatic birth asphyxia. :IndianPediatr 1991 Nov; 28(11): 1283-8

3. Epelman et al.,2010

4. Volpes JJ: Hypoxic- Ischemic Encephalopathy -Clinical Aspects,Neurology of the Newborn

5. Anand NK, Gupta AK, Lamba IM.: Neurosonographic abnormalities in Neonates with Hypoxic Ischaemic Encephalopathy. Indian Pediatr:1994 July.: 31 (7):767-74

6. Joseph J Volpe:Hypoxic- Ischemic Encephalopathy -Clinical Aspects,Neurology of the Newborn,Volume 899, Chapter 9, Yable 9.21-clinical correlates of parasagittal cerebral injury

7. Zhonghua Yi et al

8. Vries et al. 1987

9. Huang \& Castillo in 2008 in Peadiatric neurology by Valpe 